Tohoku J. Exp. Med., 2005, 206, 105-115

\title{
No Association of the CAG Repeat Length in Exon 1 of the Androgen Receptor Gene with Idiopathic Infertility in Turkish Men: Implications and Literature Review
}

\author{
A. Cevik Tufan, ${ }^{1,3}$ N. Lale Satiroglu-Tufan, ${ }^{2,3}$ Batu Aydinuraz, ${ }^{4}$ M. Hakan \\ Satiroglu, ${ }^{4,5}$ KaAn Aydos ${ }^{6}$ and Huseyin BagCi ${ }^{2,3}$ \\ ${ }^{1}$ Department of Histology and Embryology, ${ }^{2}$ Department of Medical Biology, \\ Pamukkale University School of Medicine, Denizli, ${ }^{3}$ Pamukkale University Re- \\ search Center for Genetic Engineering and Biotechnology, Denizli, ${ }^{4}$ Gen-Art \\ Women Health, IVF and Reproductive Biotechnology Center, Ankara, ${ }^{5}$ Depart- \\ ment of Obstetrics and Gynecology, and ${ }^{6}$ Department of Urology, Ankara Uni- \\ versity School of Medicine, Ankara, Turkey
}

Tufan, A.C., Satiroglu-Tufan, N.L., Aydinuraz, B., Satiroglu, M.H., Aydos, K. and HusEyin, B. No Association of The CAG Repeat Length in Exon 1 of the Androgen Receptor Gene with Idiopathic Infertility in Turkish Men: Implications and Literature Review. Tohoku J. Exp. Med., 2005, 206 (2), 105-115 — While the correlation between the CAG repeat length of the androgen receptor (AR) gene and idiopathic male infertility is still unclear, ethnic background of the population studied may play an important role in this association. The objective of this study was to determine whether changes in the CAG repeat length are associated with spermatogenic defects in Turkish infertile men. Reproductive hormone concentrations and the CAG repeat length in exon 1 of the AR gene in 47 idiopathic infertile men and 32 fertile controls were analyzed. The mean serum luteinising hormone (LH) and follicle stimulating hormone (FSH) levels were significantly higher in the infertile group than those of the control group ( $p<0.0001$ for both comparisons), whereas the mean serum testosterone level in the infertile group did not differ significantly from that in the control group $(p=0.16)$. The mean CAG repeat length of the AR gene in the infertile group did not differ significantly from that in the control group $(22.28 \pm 0.37$ vs $22.41 \pm 0.54$, respectively; $p=0.84$ ). In addition, the frequency of having a CAG repeat number ( $\geqq 24)$ was also comparable between the infertile patients and fertile controls ( $31.9 \%$ vs $40.6 \%$, respectively; $p=0.21$ ). In conclusion, reproductive hormones with elevated $\mathrm{LH}$ and $\mathrm{FSH}$, and normal or low testosterone levels were suggestive of partial impairment of testicular function. However, no statistically significant relationship between the length of the CAG repeat and idiopathic impaired sperm production was observed in the Turkish population studied. These results support the findings of previously published European studies, but are contrary to the findings from Caucasian and North American population studies. Thus, ethnicity and genetic backgrounds seem to be important in this association, and studies from a variety of different ethnic and genetic backgrounds using

Received January 28, 2005; revision accepted for publication March 8, 2005.

Correspondence: A. Cevik Tufan, M.D., Ph.D., Assistant Professor, Pamukkale University, School of Medicine, Department of Histology and Embryology, Kinikli Kampusu, Morfoloji Binasi Kat-1, TR-20020 Kinikli, Denizli, Turkey.

e-mail: actufan@pamukkale.edu.tr 
comparable patient subgroups are valuable to further evaluate this association. androgen receptor gene; CAG repeat; male infertility; defective spermatogenesis (C) 2005 Tohoku University Medical Press

Androgens are essential steroid hormones that determine the expression of the male phenotype (Yong et al. 2000). Their actions are mediated by a single androgen receptor (AR) translocating to the nucleus upon binding to its ligand in order to regulate the expression of androgen-responsive genes. Mutations that interfere with the AR function result in the complete feminization of $46 \mathrm{XY}$ individuals and the complete androgen insensitivity syndrome. Studies have revealed that AR mutations that partially interfere with its activity can cause a wide spectrum of milder androgen insensitivity syndromes, from ambiguous genitalia in newborn infants to "idiopathic" male infertility. Since the definition of the sequence and structure of the AR gene and protein it codes, more than 300 mutations have been reported in the ligand binding and DNA binding domains, accounting probably for the most naturally mutated transcription factor known (Yaegashi et al. 1999).

Androgens acting via the AR are also required for normal spermatogenesis (van Roijen et al. 1995; McLachlan et al. 1996). The AR gene located on the long arm of the $\mathrm{X}$ chromosome at Xq11-12 expands a length of more than $90 \mathrm{~kb}$ including 8 exons (Lubahn et al. 1988; Tilley et al. 1989; Marcelli et al. 1990) that code for a protein of approximately 110-114 kDa (910-919 amino acids) with 4 functional domains (Fig. 1): exon 1 encodes the transactivation domain in the aminoterminal part of the protein (Lubahn et al. 1989; Jenster et al. 1995), exons 2 and 3 encode the DNA binding domain, exon 4 encodes the hinge domain and exons 5-8 encode the ligand binding domain (Lubahn et al. 1989; Quigley 1998). The transactivation domain makes up half the receptor $(1,586 \mathrm{bp})$ and has two polymorphic repetitive DNA sequences consisting of the trinucleotide repeats, i.e., $(\mathrm{CAG})_{\mathrm{n}}$ and $(\mathrm{GGC})_{\mathrm{n}}$ (Fig. 1).

The effect of the variation in the length of the GGC tract on AR activity is less clear compared to that of CAG tract. A few epidemiological investigations of the association between the number of GGC repeats and AR gene function have produced inconsistent results (Chen et al. 2002). On the other hand, the observation that the elongation of CAG repeat in exon 1 of the AR gene causes pathogenesis of X-linked spinal and bulbar muscular atrophy (SBMA, or Kennedy's disease) strongly suggested that this region may play an important role in AR function (La Spada et al. 1991; Belsham et al. 1992). This hypothesis has extensively been investigated and a link between idiopathic male infertility and expansion of this polymorphic CAG tract in the AR gene has been suggested by several studies within the last

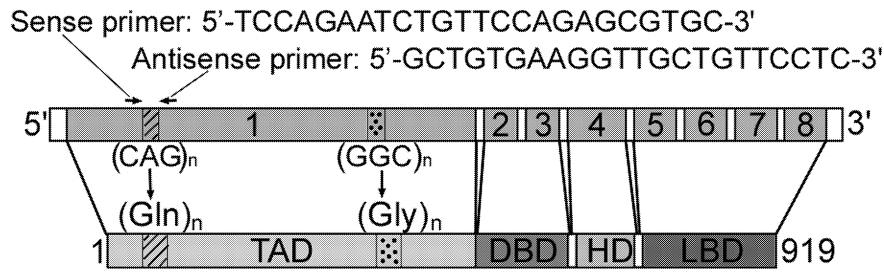

Fig. 1. Schematic representation (not to scale) of the structure of the androgen receptor gene and protein including the primer pair sequences used in this study. The gene consists of eight exons that when translated result in a protein with four main functional domains: the transactivation domain (TAD), the DNA-binding domain (DBD), the hinge domain (HD), and the ligand-binding domain (LBD). The TAD makes up half the receptor and has two polymorphic regions (shaded and dated boxes) consisting of the trinucleotide repeats, $(\mathrm{CAG})_{\mathrm{n}}$ and $(\mathrm{GGC})_{\mathrm{n}}$, respectively. Gln, Glutamine; Gly, Glycine. 
decade (Tut et al. 1997; Yoshida et al. 1999; Dowsing et al. 1999; Mifsud et al. 2001; Patrizio et al. 2001; Wallerand et al. 2001; Madgar et al. 2002; Pan et al. 2002; Asatiani et al. 2003; Casella et al. 2003; Mengual et al. 2003), whereas several others were unable to demonstrate an association (Giwercman et al. 1998; Hiort et al. 1999; Legius et al. 1999; Dadze et al. 2000; Sasagawa et al. 2000, 2001; Von Eckardstein et al. 2001; Yu and Handelsman 2001; Rajpert-De Meyts et al. 2002; Van Golde et al. 2002; Thangaraj et al. 2002; Kukuvitis et al. 2002; Erasmuson et al. 2003; Dhillon and Husain 2003; Lund et al. 2003; Tse et al. 2003; Ferlin et al. 2004). Thus, the ethnic background of the population studied may play an important role in the correlation between CAG repeat length and male infertility.

Recent studies in this field aimed to investigate the suggested association in diverse populations to further expand the information about the ethnicity and genetic backgrounds. Thus, the objective of this study was to determine for the first time whether changes in CAG repeat length of the AR gene are associated with spermatogenic defects in Turkish patients with idiopathic male infertility. A comprehensive review and summary of the previously published data concerning the correlation between CAG repeat length and male infertility is also provided in this study.

\section{Materials and Methods}

Subjects

This study on human subjects or materials was approved by the Medical Ethics Committee of the Pamukkale University, Denizli, Turkey.

A total of 47 patients of Turkish ethnic origin were recruited from Gen-Art, IVF and Reproductive Biotechnology Center, Ankara, Turkey. All of these patients had non-obstructive impairment of spermatogenesis. Moreover, none of these patients showed any clinical indication of SBMA. Control subjects were 32 males of Turkish ethnic origin and of proven fertility, who have fathered at least one child by natural conception. Semen parameters were evaluated according to published recommendations (World Health Organization 1996). Semen analysis of the patients was performed at least twice at 4-8 week intervals after at least 2 days of abstinence, and the mean result recorded. The 47 patients were divided into subgroups according to the severity of the defects in spermatogenesis: 18 had no spermatozoa in ejaculate (azoospermia), 7 had a sperm concentration of $<3 \times 10^{6} / \mathrm{ml}$ ejaculate (severe oligozoospermia), 5 had a sperm concentration of $3-19 \times 10^{6} / \mathrm{ml}$ ejaculate (oligozoospermia) and 17 had a sperm concentration of $\geqq 20 \times$ $10 \% \mathrm{ml}$ ejaculate with poor progressive motility within 1 $\mathrm{h}$ of ejaculation ( $\leqq 25 \%$ class $\mathrm{a}$, or $\leqq 50 \%$ class a and $\mathrm{b}$ ) and/or sperm morphology ( $\leqq 30 \%)$. Ages of the fertile controls ranged from 28 to 60 (mean $37.3 \pm 8.4$ ) and that of infertile patients ranged from 26 to 54 (mean $33.7 \pm$ 5.7).

Blood was taken for DNA extraction and for the measurement of reproductive hormone ( $\mathrm{LH}, \mathrm{FSH}$, and testosterone) concentrations. DNA was isolated from 5-6 ml blood samples with QIAamp DNA Blood Mini Kit method (Qiagen, Hilden, Germany) according to the manufacturers "blood and body fluid protocol". The details of the reproductive hormone concentrations for fertile controls and infertile men are summarized in Table 1.

Polymerase chain reaction (PCR) of the AR gene and trinucleotide analysis

The genomic DNA samples of all the subjects were blind-coded and the CAG repeat length of the AR gene was assessed by means of a PCR with primers specific for the repeat segment (sense primer: $5^{\prime}$-TCCAGAATCT GTTCCAGAGCGTGC, and antisense primer: 5'GCTGTGAAGGTTGCTGTTCCTC; Mifsud et al. 2001; Fig. 1). Sense and antisense strands were directly sequenced with an Amersham DYEnamic ET Terminator Cycle Sequencing Kit (Amersham Biosciences Corp., Piscataway, NJ, USA) and an ABI PRISM ${ }^{\circledR} 310$ (AME Bioscience Ltd., London, UK) DNA sequencer (performed at Iontek Ltd., Istanbul, Turkey).

\section{Statistical analysis}

Results were statistically evaluated using the MannWhitney's U-test and the test for difference between two population proportions. $p<0.05$ was taken as statistically significant for both tests.

\section{RESUlts}

The mean serum LH level in the infertile group was significantly higher than that of the control group $(6.99 \pm 0.74 \mathrm{IU} / 1$ [range 2.2-13.8] vs $3.35 \pm 0.43 \mathrm{IU} / 1$ [range 1.9-5.9], respectively; $p$ $<0.0001$ ) (Table 1). The mean serum FSH level in the infertile group was also significantly higher 
TABLE 1. Hormonal features of fertile controls and infertile men with idiopathic spermatogenic disorder

\begin{tabular}{|c|c|c|c|c|c|}
\hline \multirow{2}{*}{ Study Groups } & \multirow{2}{*}{$n$} & \multirow{2}{*}{$\begin{array}{c}\text { Age } \\
\text { (years) }\end{array}$} & \multicolumn{3}{|c|}{ Hormone concentration (mean \pm S.E. [range]) } \\
\hline & & & FSH (IU/l) & LH (IU/l) & Testosterone (nmol/l) \\
\hline Fertile controls & 32 & $28-74$ & $3.54 \pm 0.51(1.1-5.43)$ & $3.35 \pm 0.43(1.9-5.9)$ & $21.79 \pm 1.92(10.3-27.5)$ \\
\hline Infertile men ${ }^{* *}$ & 47 & $26-54$ & $13.53 \pm 1.87^{*}(3.4-36)$ & $6.99 \pm 0.74^{*}(2.2-13.8)$ & $18.45 \pm 1.41(3.8-27.8)$ \\
\hline $\begin{array}{l}\text { Severe oligozoo- } \\
\text { azoospermia }^{* * * *}\end{array}$ & 25 & $26-54$ & $15.97 \pm 1.88^{*}(5.7-36)$ & $7.76 \pm 1.05^{*}(4.2-13.8)$ & $17.52 \pm 2.2(3.8-27.8)$ \\
\hline
\end{tabular}

Normal hormone ranges: follicle stimulating hormone (FSH), 1.5-8.0 IU/l; luteinising hormone (LH), 1.5-6.0 IU/1; and testosterone, $9.0-34.0 \mathrm{nmol} / \mathrm{l}$.

"Statistically different from fertile controls by Mann-Whitney's U-test at $p<0.05 ;{ }^{* *}$ Cumulative;

${ }^{* * *}$ These patients were selected from the cumulative infertile group according to the criteria given in materials and methods section.

than that in the control group $(13.53 \pm 1.87 \mathrm{IU} / 1$ [range 3.44-36] vs $3.54 \pm 0.51 \mathrm{IU} / 1$ [range 1.1-5.43], respectively; $p<0.0001$ ) (Table 1). In contrast, the mean serum testosterone level in the infertile group did not differ significantly from that in the control group $(18.45 \pm 1.41 \mathrm{nmol} / \mathrm{l}$ [range 3.8-27.8] vs $21.79 \pm 1.92 \mathrm{nmol} / 1$ [range 10.3-27.5], respectively; $p=0.16$ ) (Table 1 ). The same trend with more significant results was also observed when severe oligozoo-azoospermic patients were tested in comparison to the fertile controls (Table 1).

The mean of the AR gene CAG repeat length in the infertile group was $22.28 \pm 0.37$ (range 18-29), while that of fertile controls was $22.41 \pm$ 0.54 (range 16-29), and the difference was statistically not significant ( $p=0.84$, Table 2$)$. The mean length of the AR gene CAG tract in individ-

TABLE 2. (CAG) repeat numbers of fertile controls and infertile men with idiopathic spermatogenic disorder

\begin{tabular}{|c|c|c|c|}
\hline Study groups & $n$ & Age (years) & $\begin{array}{l}\text { CAG repeat number } \\
\text { (mean } \pm \text { S.E. [range]) }\end{array}$ \\
\hline Fertile controls & 32 & $28-60$ & $22.41 \pm 0.54(16-29)$ \\
\hline Infertile men (cumulative) & 47 & $26-54$ & $22.28 \pm 0.34(18-29)$ \\
\hline Oligozoo-azoospermia ${ }^{* *}$ & 30 & $26-54$ & $21.6 \pm 0.39(18-25)$ \\
\hline $\begin{array}{l}\text { Poor motility and/or } \\
\text { morphology only }{ }^{* *}\end{array}$ & 17 & $31-46$ & $23.47 \pm 0.68(19-29)$ * \\
\hline $\begin{array}{l}\text { Oligozoo-/severe } \\
\text { oligozoospermia with poor } \\
\text { motility and/or morphology }\end{array}$ & 11 & $31-49$ & $21.18 \pm 0.71(18-25)$ \\
\hline Oligozoospermia $^{* *}$ & 5 & $32-36$ & $21.0 \pm 1.14(18-25)$ \\
\hline Severe oligozoospermia ${ }^{* *}$ & 7 & $30-49$ & $21.85 \pm 0.98(18-25)$ \\
\hline Azoospermia ${ }^{* *}$ & 18 & $26-54$ & $21.67 \pm 0.46(19-25)$ \\
\hline $\begin{array}{l}\text { Severe oligozoo-azoospermia } \\
\text { (combined) }{ }^{* *}\end{array}$ & 25 & $26-54$ & $21.72 \pm 0.42(18-25)$ \\
\hline
\end{tabular}

${ }^{*}$ Statistically different from Oligozoo-Azoospermia group by Mann Whitney's U-test at $p<0.05$.

** Patients in these subgroups were selected from the cumulative infertile group according to the criteria given in materials and methods section. 

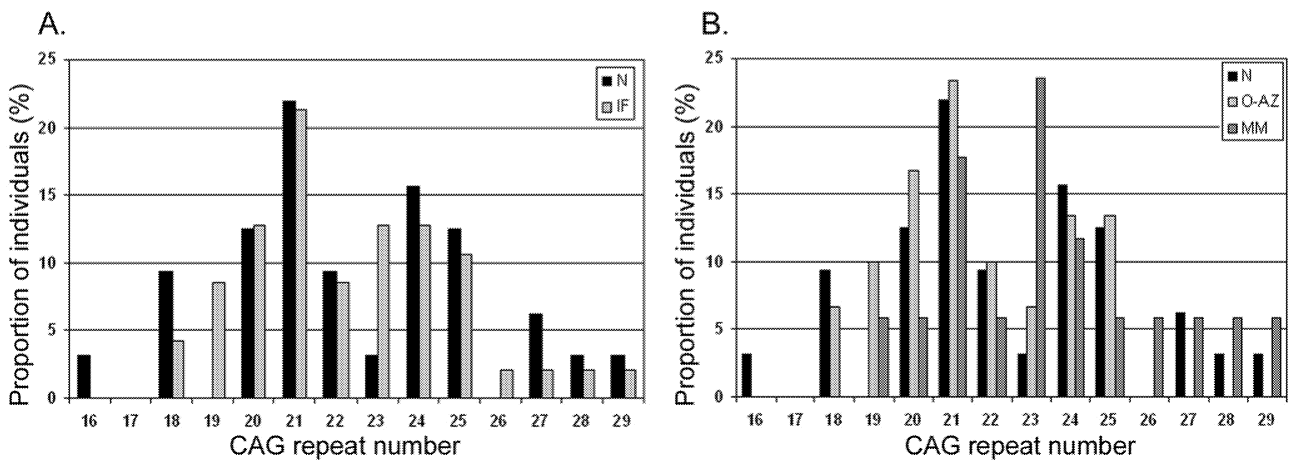

Fig. 2. Distribution of the CAG repeat sizes in exon 1 of the AR gene of fertile controls and infertile men in general (A), fertile controls, oligo-azoospermia group, and poor motility/morphology only group (B). F, fertile controls; IF, infertile men in general; O-AZ, oligo200-azoospermia group; MM, poor motility/morphology only group.

ual specific patient subgroups, i.e., oligozoo-azoospermia $(n=30)$, poor motility/morphology only $(n=17)$, oligozoo-severe oligozoospermia with poor motility/morphology $(n=11)$, oligozoospermia only $(n=5)$, severe oligozoospermia only (n $=7)$, azoospermia only $(n=18)$, severe oligozooazoospermia $(n=25)$, were also comparable to that of fertile controls (Table 2). The highest mean $C A G$ repeat number was observed in the poor motility/morphology only group (mean $23.47 \pm 0.68$, range 19-29), however, this was only significantly higher than the CAG repeat number of the oligozoo-azoospermic group (mean $21.6 \pm 0.39$, range 18-25) but not from the fertile controls (Table 2). In addition, the frequency of having a CAG repeat number $(\geqq 24)$ was $31.9 \%$ in infertile men versus $40.6 \%$ in fertile controls $(p$ $=0.21)$, whereas the frequency of having a CAG repeat number $(\geqq 26)$ was $8.5 \%$ in infertile men versus $12.5 \%$ in fertile controls $(p=0.28)$ while non of which was statistically significant (Fig. 2 and Table 3).

\section{Discussion}

Infertility affects $10-15 \%$ of all couples, and impaired sperm production accounts for about half of these cases. The cause of defective spermatogenesis, however, remains largely obscure. Androgens are required for normal spermatogenesis, i.e., they play an important role in round spermatid development, attachment to Sertoli cells and elongation of spermatids (van Roijen et al. 1995; McLachlan et al. 1996). However, most males with impaired spermatogenesis have normal serum androgen levels. Therefore, attention was focused on the AR as a possible cause of the impaired spermatogenesis in subjects with idiopathic male infertility. It has long been postulated that defects in the AR gene can lead to partial or complete spermatogenic failure (Aiman et al. 1979; Aiman and Griffin 1982) and more recently it has been shown that impaired function of the AR induces abnormalities in androgen action resulting in abnormal conditions such as androgen insensitivity syndrome (AIS) and infertility (Yong et al. 2000).

As mentioned earlier the $A R$ gene contains two polymorphic trinucleotide repeat loci: $(\mathrm{CAG})_{\mathrm{n}}$ and $(\mathrm{GGC})_{\mathrm{n}}$, which code for polyglutamine and polyglycine tracts, respectively. Both loci are located in exon 1, which encodes the transactivation domain of the receptor protein (Fig. 1). Expansion of the polyglutamine segment in the male leads to SBMA, a fatal neuromuscular disease associated with low virilization, severe oligozoo-azoospermia, testicular atrophy, and reduced fertility (La Spada et al. 1991; Belsham et al. 1992). Relatively short polyglutamine tracts with or without associated polyglycine tract changes have been linked to an increased risk of prostate cancer, an androgen-dependent tumor (Irvine et al. 1994). 


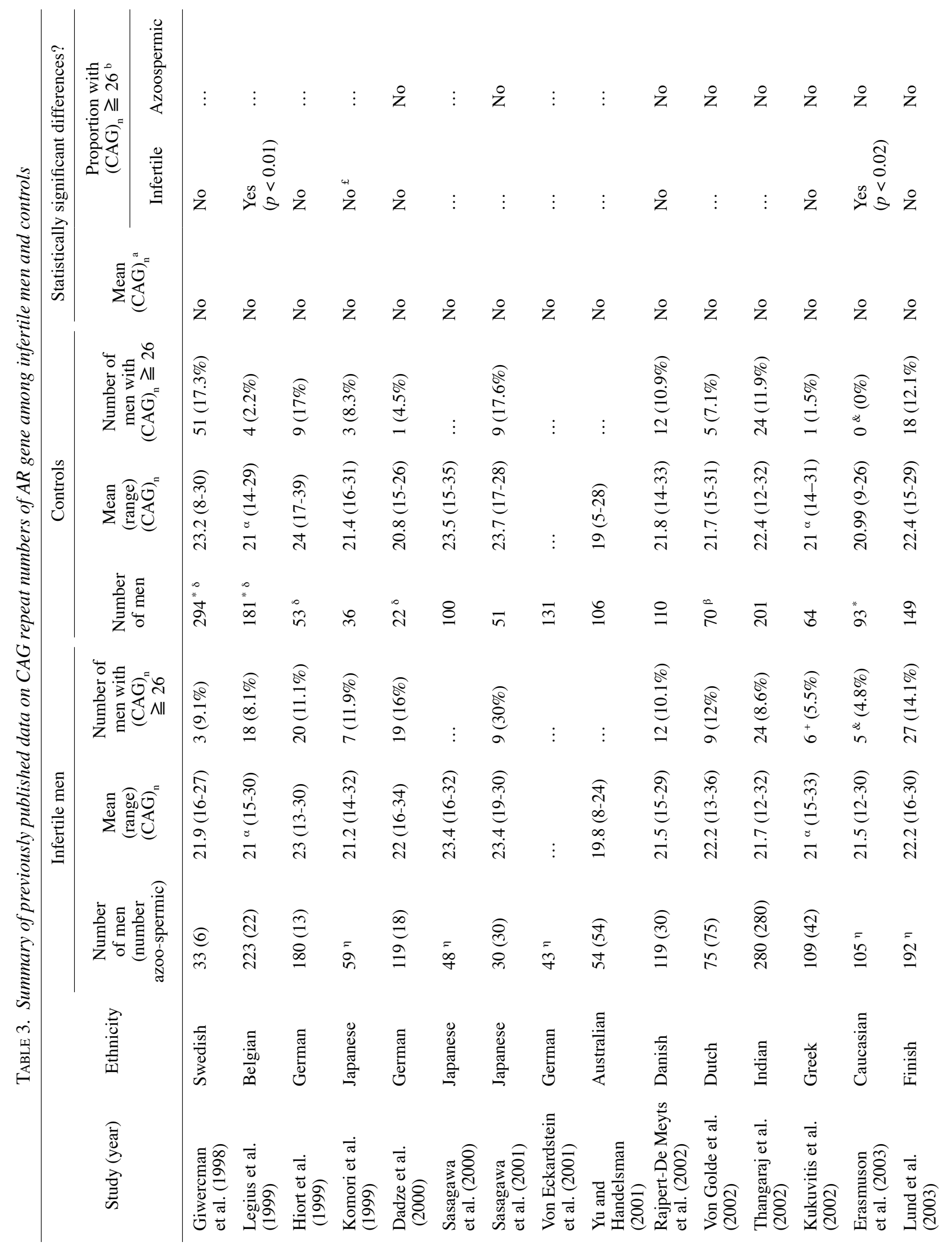




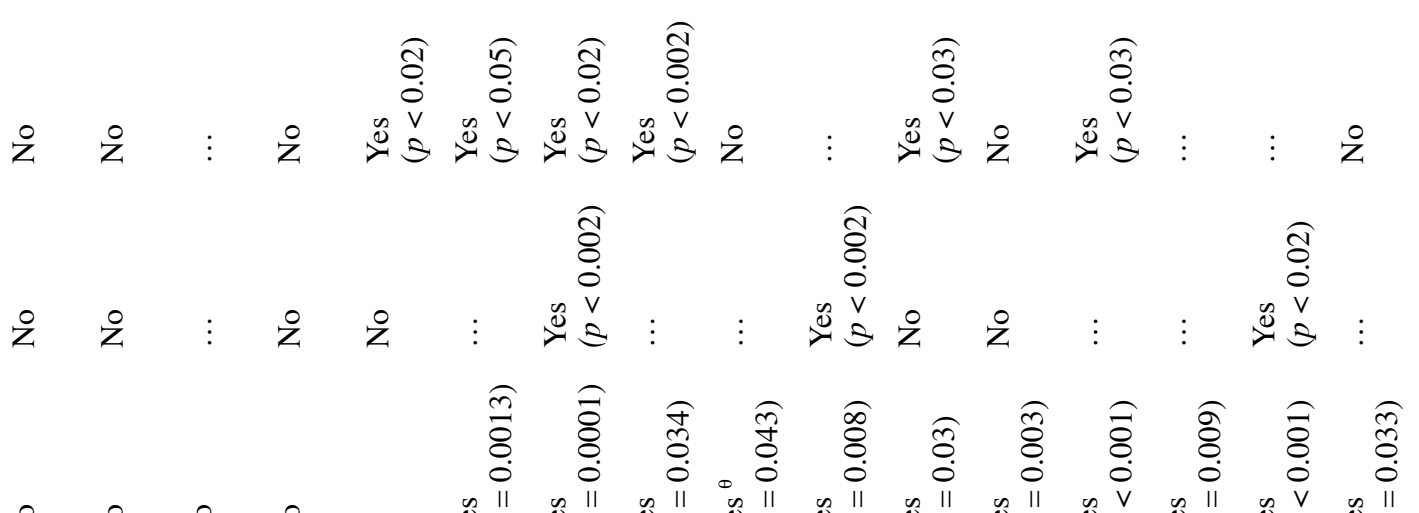

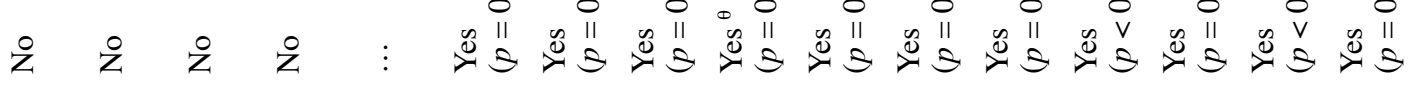

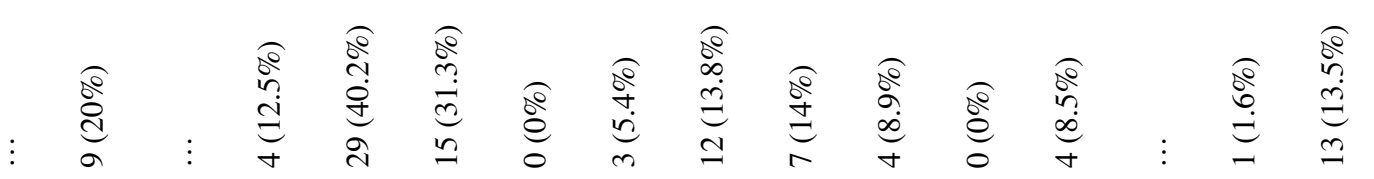

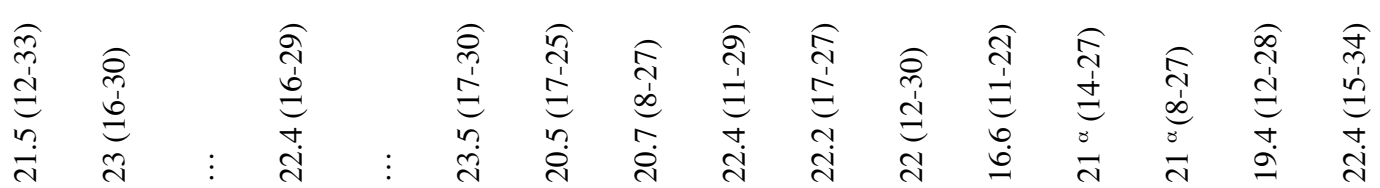

คิ ๆ

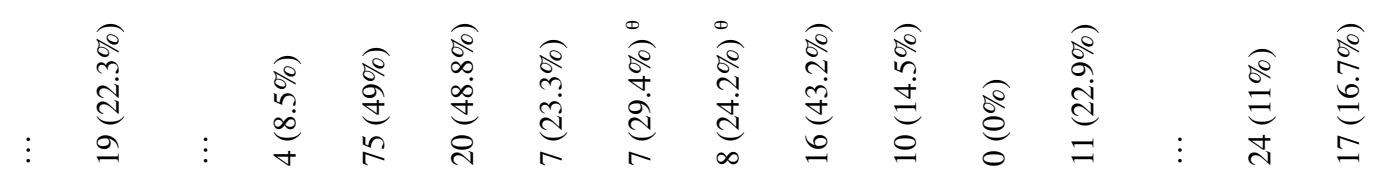

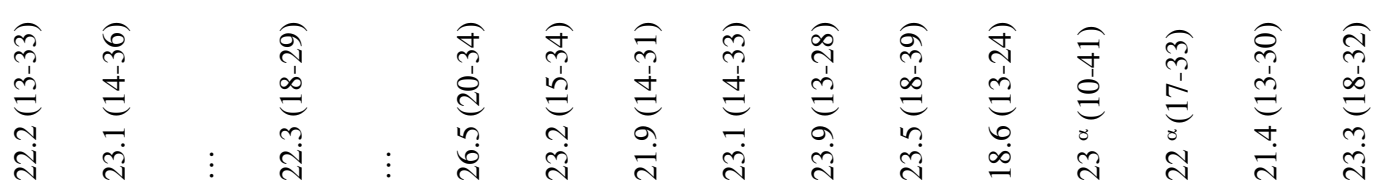

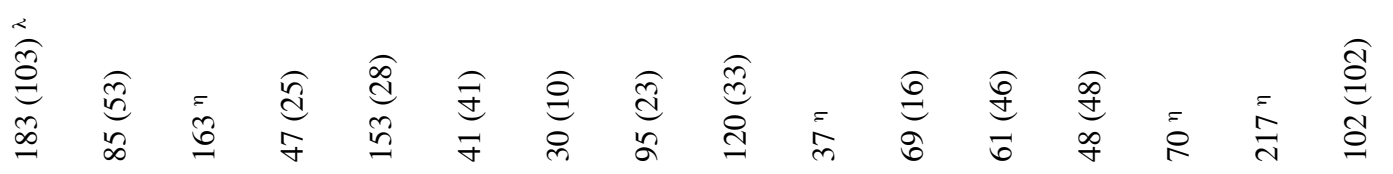

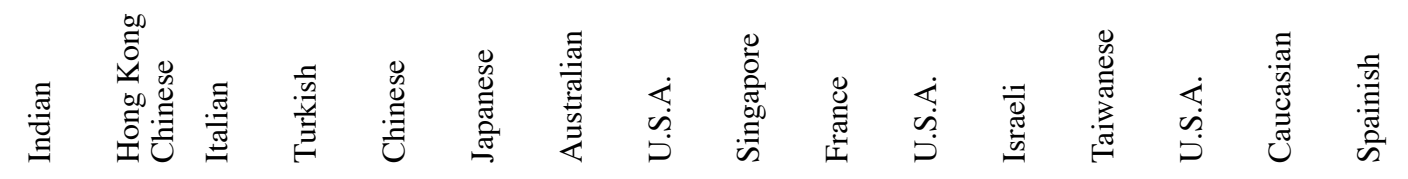

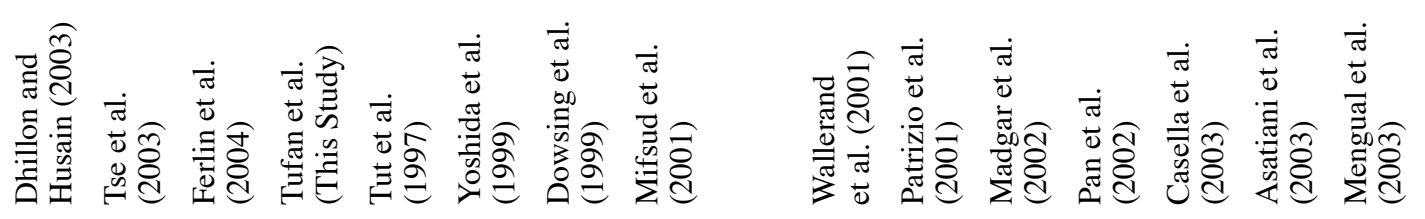

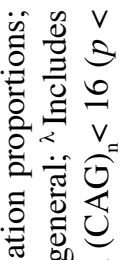

竞.结

를

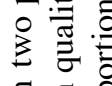

ฮี อิ

$\sum_{0} \sum_{0}$

0 0

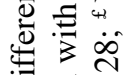

$\exists \sum_{=}^{0} \hat{0}$

氙过

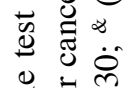

$\stackrel{\text { षे }}{\mathrm{I}}$

คิ

iิ $\tilde{E}$

过

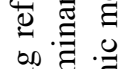

卷

营

․ㅗㅀ

월

, $\sum_{0}^{\infty}$

㝓

\&

再 
Based on this information, in a study of exon 1 of the AR gene in infertile males of predominantly (60\%) Chinese ethnic origin it was found that expansion of the trinucleotide (CAG) repeat and thus of the polyglutamine tract could be associated with increased risk of impaired spermatogenesis (Tut et al. 1997). This finding was then corroborated by several studies from a variety of different ethnic populations including Japanese, Caucasian, North American, French, Israeli, Taiwanese and Spanish (Yoshida et al. 1999; Dowsing et al. 1999; Mifsud et al. 2001; Wallerand et al. 2001; Patrizio et al. 2001; Madgar et al. 2002; Pan et al. 2002; Casella et al. 2003; Asatiani et al. 2003; Mengual et al. 2003). However, several others, who have investigated Swedish, Belgian, German, Japanese, Danish, Dutch, Indian, Greek, New Zealander, Finish, Hong Kong Chinese and Italian populations were unable to demonstrate an association (Giwercman et al. 1998; Legius et al. 1999; Hiort et al. 1999; Dadze et al. 2000; Sasagawa et al. 2000, 2001; Von Eckardstein et al. 2001; Yu and Handelsman 2001; Kukuvitis et al. 2002; Rajpert-De Meyts et al. 2002; Van Golde et al. 2002; Thangaraj et al. 2002; Dhillon and Husain 2003; Erasmuson et al. 2003; Lund et al. 2003; Tse et al. 2003; Ferlin et al. 2004). Interestingly, a study by Komori et al. (1999) has suggested that reduction rather than expansion of the CAG repeat ( $<16$ repeats) is closely related to impaired sperm production in an infertile Japanese population.

This study was designed to investigate the hypothesis that there is association between the length of the CAG repeat of the AR gene and various degrees of impaired sperm production in infertile males of Turkish ethnic origin. To our knowledge this is the first study showing the CAG repeat length polymorphism in the Turkish population. In addition, an extensive literature search has been performed to demonstrate the hypothesized role of ethnicity and genetic background in this association (Table 3).

The results from analyses of reproductive hormones with elevated $\mathrm{LH}$ and FSH, and normal or low testosterone levels were suggestive of partial impairment of testicular function and were in agreement with results from previously published studies (Dowsing et al. 1999; Yoshida et al. 1999). No statistically significant relationship between the length of the CAG repeat of the AR gene and idiopathic impaired sperm production was observed in the Turkish population studied ( $p=0.84$, Table 2). The frequency of having longer CAG repeat number was also not different in the infertile group compared with that of fertile controls (Fig. 2A, and Table 3). The range of the size of the CAG repeats in the infertile group was 18-29 and in the fertile control group 16-29 (Fig. 2A). Also within the subgroups of infertile males presenting with varying degrees of impaired sperm production (azoospermia, severe oligozoospermia, oligozoospermia and poor motility/morphology only group) we found no statistically significant association between the size of their respective CAG repeats or polyglutamine tracts and the severity of impaired sperm production (Table 2).

Tut et al. (1997) suggested that an enlargement of the CAG tract repeats $(\geqq 28)$ in infertile males is associated with a 4-fold increased risk of infertility, whereas Mifsud et al. (2001) reported the odds ratio for azoospermia as 7-fold higher for patients with $\geqq 26$ CAG repeats than in those with $<26$ CAG repeats. These studies suggested that the more severe the spermatogenic defect the higher the CAG repeat number should be. However, in this study the highest CAG repeat number observed in azoospermia group was 25 (in 4 men), whereas in the fertile control group 2 men with 27 and one man each with 28 or 29 CAG repeats were observed. Interestingly, all infertile men with CAG repeat numbers $(\geqq 26)$ were in the poor motility/morphology only subgroup in this study (one man with 26, 27, 28, or 29 CAG repeats; Fig. 2B). The highest mean CAG repeat number was observed also in the poor motility/ morphology only subgroup (mean $23.47 \pm 0.68$ ), however, this was only significantly higher than the CAG repeat number of the oligozoo-azoospermic group (mean $21.6 \pm 0.39$ ) but not from the fertile controls $(22.41 \pm 0.54)$ (Table 2). However, this significance was probably coincidental, since it disappeared when we selected the oligozoo/severe oligozoospermia patients, who at 
the same time had poor sperm motility and/or morphology $(n=11)$ and compared their mean CAG repeat number $(21.18 \pm 0.71)$ with that of fertile controls $(p=0.25)$.

It is well documented in the literature that the size of the CAG repeats in the AR gene varies in a race-specific manner (Sartor et al. 1999). An extensive literature search supported this finding and the hypothesis that ethnic background plays a major role in terms of CAG repeat number and its association with idiopathic male infertility (Table 3 ). While it is possible to explain the differences in results observed in several different populations studied with this statement, it is interesting that 3 studies originated from the same population, i.e., Japanese men, reported opposing results to each other (Yoshida et al. 1999; Komori et al. 1999; Sasagawa et al. 2001). Yoshida et al. (1999) examined 41 azoospermic Japanese men and reported the mean CAG repeat length as $26.5 \pm 3.5$ (range 20-34) in comparison to $23.5 \pm 2.9$ (range 17-30) CAG repeats in fertile controls $(p=$ 0.0013). Komori et al. (1999) examined 59 Japanese infertile men with oligozoospermia in general and found that the mean CAG repeat length in infertile men did not differ significantly from that of fertile controls $(21.2 \pm 4.2$, range $14-32$, vs $21.4 \pm 3.5$, range $16-31$, respectively), however, they reported that the frequency of having CAG repeats $(<16)$ was significantly higher in infertile men $(p<0.05)$. Both of these studies suggested that either expansion (Yoshida et al. 1999) or reduction (Komori et al. 1999) in CAG repeat length is associated with male idiopathic infertility. Opposing to these findings Sasagawa et al. (2001), who eaxamined 30 azoospermic Japanese men, found that the mean CAG repeat length in infertile group was $23.4 \pm 2.9$ (range 19-30) and was not statistically different from that of fertile controls $(23.7 \pm 3.2$, range $17-28)$. A similar disagreement is also true for two Australian studies, which suggested significant (Dowsing et al. 1999) and no significant (Yu and Handelsman 2001) association between the CAG repeat length and idiopathic male infertility (Table 3 ). These opposing results from the same population suggest the possibility that the infertile males included in these reports may represent a heterogeneous group with respect to the cause of defective spermatogenesis.

One of the main reasons to study the CAG repeat length in exon 1 of the AR gene has been to find a biomarker, which is associated with idiopathic male infertility. Another concern was the fact that with the increased use of intracytoplasmic sperm injection (ICSI) to treat severe male infertility, moderately expanded AR gene CAG repeats within the upper normal range would be vertically transmitted to female offspring and, therefore, perpetuate male infertility in second generation sons. Further, given that the AR CAG tract can expand during spermatogenesis (Zhang et al. 1994), it has been postulated that transmission of the AR gene by ICSI may in some cases lead to an increased risk of infertility and even SBMA in future generations. To that extend a study by Cram et al. (2000) examined the AR gene CAG repeat lengths in a large group of infertile men and those of their respective ICSIconceived daughters. They found that in 95 out of 99 cases studied, the AR CAG tracts ranging in size from 15-28 repeats exhibited stable inheritance in female offspring. Only in 4 fatherdaughter pairs, there was a discordance in the expected inheritance pattern with evidence for both CAG expansion (from 20 to 24, and from 22 to 23 ) and contraction (from 26 to 18, and from 26 to 22) of the paternal AR allele. Thus, they concluded that these findings tend to alleviate concerns regarding ICSI may promote the transmission of AR alleles with expanded CAG tracts and suggested that the risk of SBMA in second generation sons would be extremely low.

In conclusion, the literature search suggested that the chance to find an association between the polyglutamine tract length and the male idiopathic infertility in a given population is approximately $50 \%$, which indicates the major role and importance of the ethnicity and genetic backgrounds in this association. As it has been suggested in most European studies (Table 3) we were unable to show an association with the length of the CAG repeat tract of the AR gene and idiopathic male infertility in Turkish men. However, this associa- 
tion seems to be important especially in Caucasian and North American populations. It is obvious that studies from a variety of different ethnic and genetic backgrounds using comparable patient subgroups are extremely valuable to further evaluate this association.

\section{Acknowledgments}

This study was supported by The Scientific and Technical Research Council of Turkey, Ankara (TUBITAK, 104S077[SBAG-AYD-466]) and Gen-Art Women Health, IVF and Reproductive Biotechnology Center, Ankara, Turkey.

\section{References}

Aiman, J., Griffin, J.E., Gazak, J.M., Wilson, J.D. \& MacDonald, P.C. (1979) Androgen insensitivity as a cause of infertility in otherwise normal men. N. Engl. J. Med., 300, 223-227.

Aiman, J. \& Griffin, J.E. (1982) The frequency of androgen receptor deficiency in infertile men. J. Clin. Endocrinol. Metab., 54, 725-732.

Asatiani, K., von Eckardstein, S., Simoni, M., Gromoll, J. \& Nieschlag, E. (2003) CAG repeat length in the androgen receptor gene affects the risk of male infertility. Int. J. Androl., 26, 255-261.

Belsham, D.D., Yee, W.C., Greenberg, C.R. \& Wrogemann, K. (1992) Analysis of the CAG repeat region of the androgen receptor gene in a kindred with X-linked spinal and bulbar muscular atrophy. J. Neurol. Sci., 112, 133-138.

Casella, R., Maduro, M.R., Misfud, A., Lipshultz, L.I., Yong, E.L. \& Lamb, D.J. (2003) Androgen receptor gene polyglutamine length is associated with testicular histology in infertile patients. J. Urol., 169, 224-227.

Chen, C., Lamharzi, N., Weiss, N.S., Etzioni, R., Dightman, D.A., Barnett, M., DiTommaso, D. \& Goodman, G. (2002) Androgen receptor polymorphisms and the incidence of prostate cancer. Cancer Epidemiol. Biomarkers Prev., 11, 1033-1040.

Cram, D.S., Song, B., McLachlan, R.I. \& Trounson, A.O. (2000) CAG trinucleotide repeats in the androgen receptor gene of infertile men exhibit stable inheritance in female offspring conceived after ICSI. Mol. Hum. Reprod., 6, 861-866.

Dadze, S., Wieland, C., Jakubiczka, S., Funke, K., Schroder, E., Royer-Pokora, B., Willers, R. \& Wieacker, P.F. (2000) The size of the CAG repeat in exon 1 of the androgen receptor gene shows no significant relationship to impaired spermatogenesis in an infertile Caucasoid sample of German origin. Mol. Hum. Reprod., 6, 207-214.

Dhillon, V.S. \& Husain, S.A. (2003) Cytogenetic and molecular analysis of the Y chromosome: absence of a significant relationship between CAG repeat length in exon 1 of the androgen receptor gene and infertility in Indian men. Int. J. Androl., 26, 286-295.

Dowsing, A.T., Yong, E.L., Clark, M., McLachlan, R.I., de Kretser, D.M. \& Trounson, A.O. (1999) Linkage between male infertility and trinucleotide repeat expansion in the androgen-receptor gene. Lancet, 354, 640-643.

Erasmuson, T., Sin, I.L. \& Sin, F.Y. (2003) Absence of associa- tion of androgen receptor trinucleotide expansion and poor semen quality. Int. J. Androl., 26, 46-51.

Ferlin, A., Bartoloni, L., Rizzo, G., Roverato, A., Garolla, A. \& Foresta, C. (2004) Androgen receptor gene CAG and GGC repeat lengths in idiopathic male infertility. Mol. Hum. Reprod., 10, 417-421.

Giwercman, Y. L., Xu, C., Arver, S., Pousette, A. \& Reneland, R. (1998) No association between the androgen receptor gene CAG repeat and impaired sperm production in Swedish men. Clin. Genet., 54, 435-436.

Hiort, O., Horter, T., Schulze, W., Kremke, B. \& Sinnecker, G. H. (1999) Male infertility and increased risk of diseases in future generations. Lancet, 354, 1907-1908.

Irvine, R.A., Yu, M.C., Ross, R.K. \& Coetzee, G.A. (1994) The CAG and GGC microsatellites of the androgen receptor gene are in linkage disequilibrium in men with prostate cancer. Cancer Res., 54, 2861-2864.

Jenster, G., van der Korput, H.A., Trapman, J. \& Brinkmann, A.O. (1995) Identification of two transcription activation units in the N-terminal domain of the human androgen receptor. J. Biol. Chem., 270, 7341-7346.

Komori, S., Kasumi, H., Kanazawa, R., Sakata, K., Nakata, Y., Kato, H. \& Koyama, K. (1999) CAG repeat length in the androgen receptor gene of infertile Japanese males with oligozoospermia. Mol. Hum. Reprod., 5, 14-16.

Kukuvitis, A., Georgiou, I., Bouba, I., Tsirka, A., Giannouli, C.H., Yapijakis, C., Tarlatzis, B., Bontis, J., Lolis, D., Sofikitis, N. \& Papadimas, J. (2002) Association of oestrogen receptor alpha polymorphisms and androgen receptor CAG trinucleotide repeats with male infertility: a study in 109 Greek infertile men. Int. J. Androl., 25, 149-152.

La Spada, A.R., Wilson, E.M., Lubahn, D.B., Harding, A.E. \& Fischbeck, K.H. (1991) Androgen receptor gene mutations in X-linked spinal and bulbar muscular atrophy. Nature, 352, 77-79.

Legius, E., Vanderschueren, D., Spiessens, C., D’Hooghe, T. \& Matthijs, G. (1999) Association between CAG repeat number in the androgen receptor and male infertility in a Belgian study. Clin. Genet., 56, 166-167.

Lubahn, D.B., Joseph, D.R., Sullivan, P.M., Willard, H.F., French, F.S. \& Wilson, E.M. (1988) Cloning of human androgen receptor complementary DNA and localization to the X chromosome. Science, 240, 327-330.

Lubahn, D.B., Brown, T.R., Simental, J.A., Higgs, H.N., Migeon, C.J., Wilson, E.M. \& French, F.S. (1989) Sequence of the intron/exon junctions of the coding region of the human androgen receptor gene and identification of a point mutation in a family with complete androgen insensitivity. Proc. Natl. Acad. Sci. USA, 86, 9534-9538.

Lund, A., Tapanainen, J.S., Lahdetie, J., Savontaus, M.L. \& Aittomaki, K. (2003) Long CAG repeats in the AR gene are not associated with infertility in Finnish males. Acta Obstet. Gynecol. Scand., 82, 162-166.

Madgar, I., Green, L., Kent-First, M., Weissenberg, R., Gershoni-Baruch, R., Goldman, B. \& Friedman, E. (2002) Genotyping of Israeli infertile men with idiopathic oligozoospermia. Clin. Genet., 62, 203-207.

Marcelli, M., Tilley, W.D., Wilson, C.M., Griffin, J.E., Wilson, J.D. \& McPhaul, M.J. (1990) Definition of the human androgen receptor gene structure permits the identification of mutations that cause androgen resistance: premature termination of the receptor protein at amino acid residue 588 causes complete androgen resistance. Mol. Endocrinol., 4, 1105-1116 
McLachlan, R.I., Wreford, N.G., O'Donnell, L., de Kretser, D.M. \& Robertson, D.M. (1996) The endocrine regulation of spermatogenesis: independent roles for testosterone and FSH. J. Endocrinol., 148, 1-9.

Mengual, L., Oriola, J., Ascaso, C., Ballesca, J.L. \& Oliva, R. (2003) An increased CAG repeat length in the androgen receptor gene in azoospermic ICSI candidates. J. Androl., 24, 279-284.

Mifsud, A., Sim, C.K., Boettger-Tong, H., Moreira, S., Lamb, D.J., Lipshultz, L.I. \& Yong, E.L. (2001) Trinucleotide (CAG) repeat polymorphisms in the androgen receptor gene: molecular markers of risk for male infertility. Fertil. Steril., 75, 275-281.

Pan, H., Li, Y.Y., Li, T.C., Tsai, W.T., Li, S.Y. \& Hsiao, K.M. (2002) Increased (CTG/CAG)(n) lengths in myotonic dystrophy type 1 and Machado-Joseph disease genes in idiopathic azoospermia patients. Hum. Reprod., 17, 1578-1583.

Patrizio, P., Leonard, D.G., Chen, K.L., Hernandez-Ayup, S. \& Trounson, A.O. (2001) Larger trinucleotide repeat size in the androgen receptor gene of infertile men with extremely severe oligozoospermia. J. Androl., 22, 444-448.

Quigley, C.A. (1998) The Androgen Receptor. In: Physiology and Pathophysiology, 2nd ed., Springer, Heidelberg, pp. 33-106.

Rajpert-De Meyts, E., Leffers, H., Petersen, J.H., Andersen, A.G., Carlsen, E., Jorgensen, N. \& Skakkebaek, N.E. (2002) $\mathrm{CAG}$ repeat length in androgen-receptor gene and reproductive variables in fertile and infertile men. Lancet, 359, 44-46.

Sartor, O., Zheng, Q. \& Eastham, J.A. (1999) Androgen receptor gene $\mathrm{CAG}$ repeat length varies in a race-specific fashion in men without prostate cancer. Urology, 53, 378-380.

Sasagawa, I., Suzuki, Y., Tateno, T., Nakada, T., Muroya, K. \& Ogata, T. (2000) CAG repeat length of the androgen receptor gene in Japanese males with cryptorchidism. Mol. Hum. Reprod., 6, 973-975.

Sasagawa, I., Suzuki, Y., Ashida, J., Nakada, T., Muroya, K. \& Ogata, T. (2001) CAG repeat length analysis and mutation screening of the androgen receptor gene in Japanese men with idiopathic azoospermia. J. Androl., 22, 804-808.

Thangaraj, K., Joshi, M.B., Reddy, A.G., Gupta, N.J., Chakravarty, B. \& Singh, L. (2002) CAG repeat expansion in the androgen receptor gene is not associated with male infertility in Indian populations. J. Androl., 23, 815-818.

Tilley, W.D., Marcelli, M., Wilson, J.D. \& McPhaul, M.J. (1989) Characterization and expression of a cDNA encoding the human androgen receptor. Proc. Natl. Acad. Sci. USA, 86, 327-331.
Tse, J.Y., Liu, V.W., Yeung, W.S., Lau, E.Y., Ng, E.H. \& Ho, P.C. (2003) Molecular analysis of the androgen receptor gene in Hong Kong Chinese infertile men. J. Assist. Reprod. Genet., 20, 227-233.

Tut, T.G., Ghadessy, F.J., Trifiro, M.A., Pinsky, L. \& Yong, E.L. (1997) Long polyglutamine tracts in the androgen receptor are associated with reduced trans-activation, impaired sperm production, and male infertility. J. Clin. Endocrinol. Metab., 82, 3777-3782.

Van Golde, R., Van Houwelingen, K., Kiemeney, L., Kremer, J., Tuerlings, J., Schalken, J. \& Meuleman, E. (2002) Is increased CAG repeat length in the androgen receptor gene a risk factor for male subfertility? J. Urol., 167, 621-623.

Van Roijen, J.H., Van Assen, S., Van Der Kwast, T.H., De Rooij, D.G., Boersma, W.J,, Vreeburg, J.T. \& Weber, R.F. (1995) Androgen receptor immunoexpression in the testes of subfertile men. J. Androl., 16, 510-516.

Von Eckardstein, S., Syska, A., Gromoll, J., Kamischke, A., Simoni, M. \& Nieschlag, E. (2001) Inverse correlation between sperm concentration and number of androgen receptor CAG repeats in normal men. J. Clin. Endocrinol. Metab., 86, 2585-2590.

Wallerand, H., Remy-Martin, A., Chabannes, E., Bermont, L., Adessi, G.L. \& Bittard, H. (2001) Relationship between expansion of the CAG repeat in exon 1 of the androgen receptor gene and idiopathic male infertility. Fertil. Steril., 76, 769-774.

Yaegashi, N., Uehara, S., Senoo, M., Sato, J., Fujiwara, J., Funato, T., Sasaki, T. \& Yajima, A. (1999) Point mutations in the steroid-binding domain of the androgen receptor gene of five Japanese patients with androgen insensitivity syndrome. Tohoku J. Exp. Med., 187, 263-272.

Yong, E.L, Lim, L.S, Wang, Q., Mifsud, A., Lim, J., Ong, Y.C. \& Sim, K.S. (2000) Androgen receptor polymorphisms and mutations in male infertility. J. Endocrinol. Invest., 23, 573-577.

Yoshida, K.I., Yano, M., Chiba, K., Honda, M. \& Kitahara, S. (1999) CAG repeat length in the androgen receptor gene is enhanced in patients with idiopathic azoospermia. Urology, 54, 1078-1081.

Yu, B. \& Handelsman, D.J. (2001) Pharmacogenetic polymorphisms of the AR and metabolism and susceptibility to hormone-induced azoospermia. J. Clin. Endocrinol. Metab., 86, 4406-4411.

Zhang, L., Leeflang, E. P., Yu, J. \& Arnheim, N. (1994) Studying human mutations by sperm typing: instability of CAG trinucleotide repeats in the human androgen receptor gene. Nat. Genet., 7, 531-535. 